NBER WORKING PAPER SERIES

\title{
RETIREMENT OUTCOMES IN THE HEALTH AND RETIREMENT STUDY
}

\author{
Alan L. Gustman \\ Thomas L. Steinmeier \\ Working Paper 7588 \\ http://www.nber.org/papers/w7588 \\ NATIONAL BUREAU OF ECONOMIC RESEARCH \\ 1050 Massachusetts Avenue \\ Cambridge, MA 02138 \\ March 2000
}

We would like to acknowledge support from the National Institute on Aging and from a Social Security Administration grant to the University of Michigan Retirement Research Center, with subcontracts to the National Bureau of Economic Research and Dartmouth College. Charlie Brown and David Weir provided helpful comments. We also would like to acknowledge support for research assistance provided by the Health and Retirement Study, and to thank Nahid Tabatabai, Octavian Petrescu and Dorothy Nordness for their excellent research assistance. This paper is part of the Aging and Labor Studies Programs at the National Bureau of Economic Research. All opinions are those of the authors and not of the supporting agencies, the Health and Retirement Study, or the National Bureau of Economic Research.

(C) 2000 by Alan L. Gustman and Thomas L. Steinmeier. All rights reserved. Short sections of text, not to exceed two paragraphs, may be quoted without explicit permission provided that full credit, including (C) notice, is given to the source. 
Retirement Outcomes in the Health and Retirement Study

Alan L. Gustman and Thomas L. Steinmeier

NBER Working Paper No. 7588

March 2000

JEL No. H55, J14, J26

\begin{abstract}
This study examines retirement outcomes in the first four waves of the Health and Retirement Study. Measured retirement is seen to differ, sometimes substantially, with the definition of retirement used and among various groups analyzed. Moreover, these differences vary with the wave of the survey as respondents age. Retirement is comprised of a complex set of flows among states representing full time work, partial retirement and complete retirement. Seventy seven percent of transitions continue in the same or equivalent states between adjoining waves of the HRS; 17 percent involve a move from greater to lesser labor force participation, and 6 percent involve a move from states of lesser to greater labor force participation. Twenty two percent of the sample report they were partially retired at some time in the first four waves, and by age 65 , over a fifth of the population is partially retired. Altogether, 14 percent of the sample experienced a reversal in the course of the survey, moving from a state of less work to a state of more work. Comparing retirement flows for men between the HRS and the 1969-1979 Retirement History Study, the large spike in the population leaving full time work at age 65 observed in the RHS is reduced to half its original size in the HRS, while the share leaving full time work at age 62 has almost doubled over time. The results presented here should help researchers to improve their understanding of the structure of the dependent variable in retirement studies.
\end{abstract}

\author{
Alan L. Gustman \\ Department of Economics \\ Dartmouth College \\ Hanover, N.H. 03755 \\ and NBER \\ alan.1.gustman@dartmouth.edu
}

Thomas L. Steinmeier

Department of Economics

Texas Tech University

Lubbock, TX 79409

thomas.steinmeier@TTU.edu 
This paper analyzes retirement outcomes in the first four waves of the Health and Retirement Study (HRS). We have a number of motivations for pursuing this topic.

First, we would like to understand how the amount of retirement, and by implication any estimated retirement equations, depend upon the definition of retirement a study adopts. There are many different measures of retirement status, from measures based on self reported status, to measures based on hours of work by week or by year, to indicators of whether the individual has remained in or has left a long term job, to measures based on how the individual's earnings compare to earnings in the past, to indicators based on acceptance of retirement benefits. Each definition produces a different measure of retirement outcomes, and of flows between waves of the survey among the states of not retired (full-time work, F), partially retired (P) and completely retired (R). Second, it is of interest to explore differences in retirement outcomes among demographic groups. Comparisons are made between retirement outcomes and retirement flows for women and men, and among Blacks, Whites and Hispanics. It is especially interesting to document the situation in recent years, to see how retirement patterns of women have evolved in view of the sharp changes in patterns of women's labor market participation.

Third, as a precursor to estimating retirement models, we should have a full understanding of the structure of the complex dependent variable that constitutes retirement behavior. Using the self reported definition of retirement, this paper describes the numbers of HRS respondents of different ages falling in each retirement category in each wave of the survey, the flows among various retirement states from one wave to the next, and the flows by age. 
Fourth, it is of interest to determine how the relation between retirement outcomes and age has changed over time. Pension plans and social security have changed in many ways over the past two decades, and these changes influence retirement outcomes (Anderson, Gustman and Steinmeier, 1999). To isolate some of these changes, we compare retirement outcomes in samples of men between the HRS and the earlier Retirement History Study.

Section 2 analyzes the distribution of outcomes in each wave of the HRS using a number of different definitions of retirement. Section 3 compares outcomes by race, ethnicity and gender. Using a self reported definition of retirement, Section 4 examines outcomes across the four waves of the survey. Section 4 also reports the transition rates from one state to another, and documents the many retirement patterns that are observed in the data. In Section 5 we take a more detailed look at retirement by age. Section 6 compares retirement outcomes of different cohorts of males: between samples from the 1969-79 Retirement History Study and the 1992-98 Health and Retirement Study and between HRS samples of comparable age taken in 1992 and 1998, the original HRS cohort and the new "warbabies" cohort.

\section{Outcomes Under Alternative Definitions of Retirement}

In this section we examine the distribution of respondents among various retirement categories in each of the waves of the HRS, and describe how the measured retirement outcomes depend on the definition of retirement that is used. ${ }^{1}$

${ }^{1}$ Gustman, Mitchell and Steinmeier (1995) examines the sensitivity of the rate of retirement to the measure of retirement used in wave 1 of the Health and Retirement Study. In this section we examine the sensitivity of measured retirement to the definition of retirement used in each of the first four waves of the HRS, and also consider how retirement dynamics are affected by the definition of 
Alternative definitions of retirement are given in Table 1. Outcomes under each of the alternative definitions of retirement status are reported in Table 2 for the age eligible population in the HRS, those born from 1931 to 1941 , who answered the question in the relevant wave of the survey. ${ }^{2}$

Line 1 of Table 2 indicates self reported retirement status in each of the four waves of the survey. Notice that in line 1, the probabilities of falling in each of the three retirement states, not retired at all (F), partially retired $(\mathrm{P})$ and completely retired $(\mathrm{R})$, do not add up to 1.0. Rather, there is a fourth outcome in the HRS question on self reported retirement status, question not relevant (because the individual indicates he or she does not work for pay, is a homemaker, or hasn't worked for pay, in 10 years or more in wave 1 , or in one year or more in waves 2 through 4$){ }^{3}$

retirement used.

${ }^{2}$ Sample exclusions are reported in Appendix 1. Age ineligibles and an overlap group with a spouse who fell into the HRS age range, but was incorporated into the AHEAD survey, are excluded from all waves. Attritors and those whose survey is answered by a proxy respondent are excluded only from the waves in which a respondent survey is not available. Appendix 2 reports the same statistics as in Table 2 where attritors and those with proxy responses are excluded from all waves, even those waves where a response is available.

${ }^{3}$ More specifically, the number of respondents who chose the four retirement categories in each wave of the survey are indicated in the following table:

Number of Respondents by Wave Reporting Retired, Partially Retired, Completely Retired or

\begin{tabular}{|c|c|c|c|c|}
\hline & Not Retired & Partially Retired & $\begin{array}{l}\text { Completely } \\
\text { Retired }\end{array}$ & $\begin{array}{l}\text { Question Not } \\
\text { Relevant }\end{array}$ \\
\hline Wave 1 & 6548 & 575 & 1155 & 1019 \\
\hline Wave 2 & 5219 & 801 & 1564 & 681 \\
\hline Wave 3 & 4026 & 887 & 1878 & 1037 \\
\hline
\end{tabular}


Over the four waves of the HRS, the share reporting they are not retired at all $(\mathrm{F})$ falls from 72 percent to 42 percent of age eligible respondents, while the shares reporting they are partially or completely retired each roughly doubles, from 6 percent to 13 percent for those reporting partial retirement, and from 12 percent to 27 percent for those reporting they are completely retired. Thus 10 percent of the age eligibles report the retirement status question is not relevant in wave 1,7 percent report it is not relevant in wave 2, 12 percent report the question to be not relevant in wave 3 , and 18 percent report it is not relevant in wave 4.

Lines 2 and 3 of Table 2 report retirement status using objective measures of retirement based on hours of work. Both objective measures, usual hours of work per week and usual hours per year, provide similar indications of retirement status. Thus 62 percent of respondents are classified as not retired in wave 1 because they usually work 25 or more hours a week; while 60 percent are classified as not retired in wave 1 because they usually work 1200 or more hours per year. Similar results are also found for partial and complete retirement in wave 1 with the two hours based definitions of retirement, with roughly 7 to 8 percent partially retired and 31 to 32 percent completely retired using either definition. The rates of nonretirement, partial and complete retirement change the same way between the four waves for each of the hours based definitions of retirement.

However, the objective measures of retirement status based on hours of work suggest different numbers falling in the different retirement outcome categories from those found with the self

Wave 4

*The counts in this table are unweighted. Results in the text use weights from wave 1. 
reported retirement measure. Thus the objective retirement measures suggest there are fewer individuals who are not retired, especially in wave 1, than are suggested by the self reported retirement measures. By wave 4, however, the self reported and objective measures are indicating roughly the same population shares as not retired. Therefore, the objective, hours based measures suggest that the flow out of full time work from wave 1 to wave 4 is smaller than when the self reported retirement measure is used. Notice that the share of the population completely retired is much higher according to the objective than the self reported measures. The difference is that, for the subjective retirement variable, there is a fourth category, "Not Relevant", while there are only three categories when the objective hours definitions of retirement are used. We further analyze the "Not Relevant" category in the self reported data after completing our discussion of Tables 2 and 3.

Rows 4 and 5 of Table 2 define retirement status according to whether one remains in, or has left a long term job. Thus the basic populations for these measures, 5204 and 2720 respectively in wave 1 for the two measures, consist of those who, at one time or another, held a job for either 10+ years or $20+$ years. Those who have left that job are classified as retired if they are no longer working after having left their long term jobs, or as partially retired if they are working after having left a long term job. ${ }^{4}$ Using the long term employment definition, the fraction not retired is about the same in wave 1 as it is when the hours measures are used, with a slightly higher share not retired when long term job is defined as a $20+$ year job rather than a $10+$ year job. However, the share of the relevant

\footnotetext{
${ }^{4}$ The measure of retirement based on having left a long term job reported in this paper classifies those who left a job of 10 or 20 years duration after age 45 as partially retired even if they are working full time, and even if they are in a current job that also lasts 10 or 20 years.
} 
population that is partially retired is higher using the long term job definition, since in wave 1, roughly a fifth of the population, while working, is no longer in their long term job. ${ }^{5}$ Very wide differences in the rate of partial retirement are also apparent when the self reported or hours based rates of partial retirement are compared with the rates estimated on the basis of having left a long term job. The share of the population fully retired is lower when the definition is based on long term attachment than when it is based on usual hours of work. Retirement rates over the course of the panel are higher when retirement is measured by long term attachment, especially when measured by the relative difference in the fraction fully retired between the first and fourth waves of the survey.

The next two rows of Table 2 measure retirement by the relation between usual earnings and maximum earnings, with separate measures based on hourly wage and weekly earnings. Those who are earning 60 percent or more than the maximum they earned in the past are classified as not retired, those who are working but earn less than 60 percent of the maximum recorded are partially retired, and those not working at all are fully retired. ${ }^{6}$ Fewer are classified as not retired using the wage or earnings based measures of retirement status than using the hours based measures. The difference

${ }^{5}$ Ruhm (1990) calls jobs held after leaving long term jobs "bridge jobs". One criticism of the concept of "bridge jobs" is that it mixes turnover from long term jobs, which may be observed for a variety of reasons having nothing to do with retirement behavior, with the process of phasing out of the labor market. Those in bridge jobs may be supplying a full year's effort on a job they held after leaving their long term job, with some having left their long term job well before they were contemplating retirement.

${ }^{6}$ The maximum wage is calculated for wave 1 using the wages reported in sections F, G and H. After wave 1, all wages in waves up and including that wave are also included in calculating the maximum wage. Thus for wave 3 , the maximum wage includes all observed wages reported in the past and for wave 1, plus the current wages observed in waves 2 and 3. The calculated maximum wage used in computing retirement status does not look forward, only backwards. 
widens from wave 1 through wave 4, so that the measure of the number flowing out of full time jobs between waves 1 and 4 is a few percentage points higher when the wage or earnings based definitions are used.

Rates of partial retirement are also a few percentage points higher using the wage or earnings based measures of partial retirement than when the self reported measures and hours based measures are used.

Lastly, when retirement status is based on social security receipt, the share not retired is substantially higher than under any other measure. In wave 1 none of the age eligibles are old enough to receive social security benefits from own work, and can be receiving benefits only as a surviving spouse or due to own or spouse's disability. Even by wave 4, when half the population is retired by any of the other objective measures in Table 2, only 40 percent of age eligibles are in receipt of social security benefits.

\section{Retirement Outcomes by Gender, Race and Ethnicity}

Table 3 reports the probability of being not retired by gender, race and Hispanic origin. Four of the definitions of retirement from Table 2 are used.

Men are more likely to be not retired than women; Whites are more likely to be not retired than Blacks or Hispanics. Difference in retirement rates by gender, race and ethnicity vary among the different definitions of retirement. While the differences between Whites and Blacks vary by a few percentage points across the different definitions, differences between men and women are much wider when not retired is defined as working more than 1200 hours, than when not retired is defined 
on the basis of the other definitions.

\section{Retirement Dynamics}

All of the remaining tables use the self reported definition of retirement to explore retirement dynamics. Table 4 measures the shares of the observations for the population transiting from the states indicated in the column heads in one wave, to the states indicated in the row heads in the next wave. This table summarizes the wave to wave transition rates between waves 1 and 2, waves 2 and 3, and waves 3 and 4 . Thus on average, over the four waves, 38 percent of the sample begin in nonretirement and end in the same state.

Table 4A includes 'not available' as an additional state, with 21.6 percent of responses not available in one wave or the other $(12.6+19.0-10.0)$. Observations are included in the not available category for a number of reasons: if the respondent refused to answer or answered don't know; if their survey instrument was answered by a proxy respondent, who then, following the skip pattern of the survey, would not have been asked to report the respondent's retirement status; or if the respondent was not interviewed in the wave, having attrited temporarily or permanently from the sample.

Among respondents asked about their self reported retirement status, 14.3 percent $(8.4+9.8$ - 3.9) answer, in one of two adjoining waves, that the question is not relevant Respondents who don't work for pay, are homemakers, and haven't worked for pay for ten years in wave 1, or one year in later waves, may answer not relevant to the retirement status question.

Table 4B rescales the data in Table 4A. It excludes the not available answers from the 
denominator and recomputes the remaining probabilities for the 78.5 percent of the transitions among the states of not retired, partial retirement, complete retirement and not relevant so that they add up to 100 percent. Among those transiting through the remaining four states: 49 percent continue between adjoining waves as not retired in each; 4.3 percent report they were partially retired in two adjoining waves; 12.9 percent report they were retired in adjoining waves; and 5.0 percent report the question was not relevant in two adjoining waves. Consequently, 71.0 percent of transitions involved continuing in the same state from one wave to the next.

Considering the transitions for those changing retirement status, 11.3 percent were following a simple retirement path, beginning as not retired, and proceeding either to partial retirement (5.2 percent $)$ or directly to complete retirement $(6.1$ percent $){ }^{7}$ Among the remaining transitions, 2.4 percent began with partial retirement and proceeded to complete retirement. In addition, 2.8 percent went from not retired to question not relevant, a state that is difficult to distinguish from full retirement. ${ }^{8}$

${ }^{7}$ The finding that movements to retirement involve a disproportionate share of transitions directly from full time work straight to complete retirement is consistent with earlier work, but the share of these "bang-bang" transitions is lower in these data than in the Retirement History Study (Gustman and Steinmeier, 1984). However, the RHS group was much older than the HRS sample.

${ }^{8}$ For many respondents, the states of "completely retired" and "question not relevant" appear to be equivalent. In wave 1 the respondent is asked to report retirement status as "question not relevant" if the respondent does not work for pay or is a homemaker, or has not worked for ten or more years. In subsequent waves, the respondent is asked to report retirement status as question not relevant if the respondent does not work for pay or is a homemaker, or has not worked for one or more years. Despite these instructions, among those who indicated they were completely retired in wave 1 , and reported they were either completely retired or the question was not relevant in wave 2, most continued to report in wave 2 that they were completely retired. However, among those who reported the question was not relevant in wave 1 and who reported either that they were completely retired or the question was not relevant in wave 2 , forty percent switched their answer to completely retired. Accordingly, users of the survey should be careful in how they handle those responding 
Another 0.9 percent went from partial retirement to question not relevant. ${ }^{9}$ Altogether then, 17.4 percent of transitions were moving from a state of greater labor force participation to a state of lesser labor force participation.

The remaining 11.6 percent of transitions consist of two groups: 6.1 percent of the transitions were from a state of lesser labor force participation to a state of greater labor force participation, and thus involved reversals; with 1.8 percent involving a move from partial retirement to nonretirement; 0.5 percent from retirement to nonretirement, 1.5 percent from retirement to partial retirement, and 1.8 percent and 0.5 percent from question not relevant to not retired and to partially retired respectively. The second group consists of the 5.5 percent of transitions between not relevant and retired.

Altogether then, about 71 percent of the transitions were continuations in the same state from one period to the next. Of the remaining 29 percent, about 17.4 percent were in the direction of lowering work effort, while 6.1 percent were in the direction of increasing work effort, with the other 5.5 percent involving transitions between completely retired and not relevant.

Table 5 asks a slightly different question from Table 4. Among those observed in the final states indicated in the row heads, what states did they come from?

About 89 percent of the transitions ending in nonretirement began with nonretirement; 3.4 percent involved an increase in work effort from partial retirement; 1.0 percent involved an increase in work effort from complete retirement; while 3.2 percent answered not relevant on the previous wave,

question not relevant. A number of them will be indistinguishable from the retired population.

${ }^{9}$ Note that 2.2 percent went from question not relevant to complete retirement, and 3.3 percent went from completely retired to question not relevant. 
and 3.3 percent were previously not available.

Among those ending in partial retirement, $43.7 \%$ of the transitions were from nonretirement.

Over a third (36.1 percent) were from partial retirement. An additional 12.8 percent came from complete retirement. Of the remaining transitions, 4.5 percent previously reported the question was not relevant, and for 2.8 percent of those ending in partial retirement, in the previous wave they were not available.

Among those who were completely retired in the subsequent wave, more than half $(53.1 \%)$ were fully retired in the initial state. About a fourth (25.3\%) came directly from nonretirement, and 10 percent came via partial retirement. About 8.8 percent of those reporting they were retired indicated the question was not relevant in the previous wave, and in 2.8 percent of transitions, the respondent was not available in the previous wave.

Among those ending in not relevant, 40.2 percent gave the same answer in the previous wave, while 22.8 percent of those answering not relevant previously reported they were not retired, and 26.1 percent previously reported they were completely retired. Lastly, among those ending in not available, 52.5 percent were not available in the earlier wave. The majority of the rest of those not available in subsequent waves, 29 percent, previously reported they were not retired in the initial wave.

Table 6 breaks down the columns in Table 4A according to the state where the individual originated, reporting the conditional probability of transiting from the state reported in the column head to the state reported in the row head. Thus among those beginning as not retired, 69.7 percent ended 
in nonretirement, 7.4 percent went to partial retirement, 8.8 percent went to full retirement, 4.1

percent answered that the question was not relevant on the next wave, 9.9 percent were not available for the next wave.

Among those initially indicating they were partially retired, 41.6 percent continued in that state, 23.6 percent transited to complete retirement. There were reversals to full time work among 17.8 percent of the transitions observed from partial retirement. 8.1 percent of the respondents who reported they were partially retired in one wave indicated that the question on retirement status was not relevant in the next wave, and 8.9 percent were not available to the survey for the next wave.

Among those beginning as completely retired, 63.1 percent remained in that state in the next wave, 2.5 percent returned to nonretirement status, and 7.4 percent reported themselves as partially retired in the subsequent wave. 15.9 percent of those reporting themselves as completely retired in the initial wave said the question was not relevant in the next wave, and 11 percent were not available for the next wave.

Table 7 shows the complete set of flows among the four waves of the survey. There are five panels to the table. All of the combinations in the first panel involve those who were not retired in wave $1(\mathrm{~F})$. The second panel pertains to those who were partially retired in wave $1(\mathrm{P})$, the third panel to those who were completely retired in wave $1(\mathrm{R})$, the fourth panel to those who answered the question was not relevant in wave $1(\mathrm{X})$, and the fifth panel includes those who were not available in wave 1 (.). The column heads indicate the status reported by the respondent in wave 2 . In the first column, the two letters comprising the row heads indicate the respondent's retirement status in waves 
3 and 4 respectively. For example, the first entry in the first panel of Table 7, 24.66, indicates that 24.66 percent of the combinations of retirement statuses across the four waves involved being not retired in each of the four waves, that is FFFF was the status across the four waves. The second entry in the first row of the first panel indicates that 0.43 percent of the retirement outcomes involved FPFF, not retired in wave 1, partially retired in wave 2, and not retired in waves 3 and 4 . The last entry in column 1, FF.. indicates that 3.36 percent of respondents worked full time in the first two waves and then were not available (.) for the last two waves.

From the data in Table 7, adding the fraction of the sample partially retired in wave 1 to the fraction that is partially retired in waves 2,3 and 4 in the various sequences, we find that 22 percent of the sample has reported sometime in the first four waves they were partially retired. This is below the number found for the Retirement History Study, where roughly a third were found to have ever partially retired. But the HRS sample is much younger than the RHS sample, and many more will eventually transit through the state of partial retirement.

Sixty eight percent of the sample work full time in wave 1. By wave 4, 31 percent of the sample is in full time work, but only 25 percent of the sample remained in full time work throughout all four waves.

Altogether, 14 percent of the sample experienced a reversal in the course of the survey, moving from a state of less work to a state of more work. Among the 68 percent of the sample who worked full time in the first wave of the HRS, 5 percent of the sample experience a reversal of retirement status by partially retiring or retiring and then returning to full time work. Among the 6 
percent of the sample who indicated they were partially retired in wave 1,2 percent of the sample experienced a reversal in the course of the survey and are shown to be not retired at all sometime after wave 1 . Among the 12 percent of the sample who were completely retired in wave 1,2 percent of the sample indicated in either waves 2,3 , or 4 that they were partially retired or not retired. In addition, among the 9 percent of the sample who answered not relevant in wave 1, or the 5 percent of the sample who had a missing observation in wave1, 1 percent experienced a reversal by wave 4 .

\section{Retirement By Age}

Table 8 begins the exploration of retirement status by age. The sample includes all age eligibles as in Tables 2 to 7. Panel A pertains to retirement outcomes by age for males, Panel B for females.

Starting around age 53 the proportion of males not retired begins to decline at roughly three or four percentage points per year until after age 61. Between 61 and 62 the decline is about 20 percentage points, and from 62 to 63 the proportion not retired declines about two percentage points. There is a six percentage point decline from age 63 to 64 , and an eleven percentage point decline from age 64 to 65 . Only eighteen percent of 65 year old males report themselves as not retired.

Among men who report themselves as partially retired, partial retirement rises with age, where it exceeds a fifth of the population by age 65 .

The proportion fully retired, or who answer the question is not relevant, account for those who are not working full time or partially retired. The sum of the share of men who say that the question is not relevant or who report they are fully retired rises until, between age 61 and 62 it jumps sharply 
from 30 percentage points to 43 percentage points. There is a seven percentage point jump between 63 and 64, and again between 64 and 65 . At age 65 about 41 percent of the sample still reports they are partially retired or not retired.

The decline for women in the percent not retired is also evident at age 54. There is a 14 point drop at age 62 . At age 65 only 17 percent report they are not retired. Partial retirement rises continuously with age after age 55, rising to a peak of 15 percentage points at age 64 . The proportion of the sample of women answering that the retirement question is not relevant is three to four times as high for women than men. The change in the question, allowing the non relevant response if the respondent has not worked in the past year in waves 2 through 4 , accounts for the increase in the number choosing not relevant at older ages. About 31 percent of the sample of women is working at age 65,17 percentage points as not retired, and 14 percentage points as partially retired.

Consider some of the major differences in retirement outcomes reported by women and men. At any age, men are roughly 10 percentage points more likely to be not retired than women, with the gap narrowing after age 61 . Men are 2 to 5 percentage points more likely to be partially retired than women.

Tables 9 focuses on retirement outcomes reported by respondents by age and wave. Conditioning the sample on those who did report retirement status, there are no patterns that stand out in the proportions who call themselves not retired or partially retired that suggest major differences between the waves of the survey. The fraction indicating that the question is not relevant increases 
across the waves, a change that is mirrored by a corresponding decline, of a few percentage points, in the share who report they were completely retired. This likely reflects the effect of the change in the qualification for the not relevant category in the self reported retirement status question from not having worked for ten years in wave 1 to not having worked for a year in waves 2 through 4 . The effect is modest, however.

\section{Retirement Trends Among Cohorts}

It is useful to consider how retirement behavior differs among cohorts. In 1998 a new cohort was added to the Health and Retirement Study. This group, called the Warbabies, was born from 1942 to 1947 . Thus at the time of the survey, the Warbabies were 51 to 56 years old. That is a little young to discern trends in retirement. There are clues we can examine about what to expect from this new cohort, but before we do that, it is useful to put the retirement trends in longer run perspective. Accordingly, before comparing differences between cohorts within the HRS, we compare findings from the original HRS cohort with findings from the Retirement History Study, a ten year panel study of 58 to 63 year olds in 1969 .

\section{A. Comparison Between the HRS and RHS}

Table 10 compares retirement outcomes for males between the Health and Retirement Study and the Retirement History Study. ${ }^{10}$ The results are confined to males since the RHS did not include a representative sample of women.

${ }^{10}$ For additional evidence on the trends to earlier retirement, see Anderson, Gustman and Steinmeier (1999) and Friedberg (1999). In addition to evidence from the Current Population Survey, Friedberg contains comparisons between the RHS and HRS. The first draft of this paper, containing the comparisons reported here, was completed before we became aware of her work. 
The major trends to early retirement are apparent in the data. At age 60 more than three fourths of the RHS were still at work full time, while fewer than two thirds of the males in the HRS are at work. At age 62, 60 percent of the RHS sample was at work three decades ago, while little more than a third of the HRS sample report they are not yet retired. Only at age 65 do the two samples approach each other.

Not all those who have left full time work have exited the labor force. At all ages, the proportion partially retired in the HRS sample lies well above the fraction found to be partially retired in the earlier RHS study.

Despite the larger number who are partially retired in the HRS, only through age 64 does the number retired in the HRS (the sum of the number retired plus those reporting not relevant in the HRS) exceed the comparable retirement rate in the old Retirement History Study.

The trend to earlier retirement is readily apparent in Table 11, which reports the proportion of the sample retiring by age for each of the two surveys. There was a very large spike in retirement in the RHS at age 65 with one fifth of the sample leaving full-time work. In the HRS, the comparable spike at 65 is half as large, but one fifth of the HRS sample leaves full-time work at age 62. Thirteen percent enter complete retirement between ages 61 and 62 in the HRS. In the old RHS, only 9 percent entered complete retirement at age 62.

There is a view in the retirement literature that lack of employer provided retiree health insurance and availability of Medicare eligibility at age 65 are major factors shaping retirement behavior. Nevertheless, the spike in the number entering the state of complete retirement at age 65 
has all but disappeared, and the proportion leaving full time work at age 65 has more than halved. This raises questions about the importance of Medicare eligibility and absence of employer provided retiree health insurance in promoting a spike at age 65 in retirement rates.

\section{B. Comparing 51 to 56 Year Olds in the HRS and in the Warbabies}

Although the Warbabies are a little young to have retired in great numbers, we can ask how they differ from those who were 51 to 56 in the initial year of the HRS. Table 12 compares 51 to 56 year olds in the two cohorts on a number of variables that will certainly influence retirement outcomes. There are a number of similarities between the cohorts. One major difference, seen in row 2 , is that the share of women working full time between the ages of 51 and 56 is significantly higher in the Warbabies. Another major difference, seen in rows 5 to 8 , is the sharp decline in coverage by defined benefit pension plans. This decline is obvious for both men and women. The influence of a third difference will not be apparent until the Warbaby cohort reaches its mid-sixties. As seen in the bottom row of Table 12, social security normal retirement age for the Warbabies rises for all those born after 1942 to age 66 . Both the changes in pensions and in social security may lead to some delay in retirement for the Warbaby cohort.

\section{Conclusions}

This study has examined retirement outcomes in the Health and Retirement Study. We measured how retirement outcomes vary with the definition of retirement adopted. We then examined retirement outcomes among groups, and described the dynamic structure of the complex retirement variable. Lastly, we considered changes over time, and how retirement flows found in the HRS 
differed from those in the earlier Retirement History Study.

Among our major findings are the following:

Self Reported Retirement Status: Over the four waves of the HRS, the share reporting they are not retired (F) falls from 72 percent to 42 percent of age eligible respondents, while the share reporting they are partially retired each roughly doubles, from 6 percent to 13 percent.

Retirement Based on Hours Per Year of Work: The objective hours measures of retirement suggest there are fewer individuals who are not retired, especially in wave 1, than are suggested by the self reported retirement measures. Using a definition based on working 1200 hours per year, 60 percent are classified as not retired in wave 1 . The proportions reporting they are partially retired using the hours per year definition, 8.1 percent, is only 1.8 percent higher than the percentage partially retired obtained from the self reported definition. By wave 4, the self reported and hours per year based measures are indicating roughly the same population shares as not retired and as partially retired. Similar results are obtained measuring retirement status by hours per year and hours per week of work.

Defining Retirement As Having Left A Long Term Job: Using a measure based on whether one is still in a long term job, the fraction not retired is about the same in wave 1 as it is when the hours measures are used. However, the share of the relevant population that is partially retired is higher using the long term job definition, because roughly a fifth of the population, while still working by wave 1 of the HRS, is no longer in their long term job they held until age 45 . When considering a definition of retirement based on long term job, it is important to remember that over 40 percent of the sample is 
lost when the population is confined to those who ever held a job for more than 10 years and held that job at age 45 or later, and over two thirds of the sample is lost when long tenure is defined as having held a job for more than 20 years.

Earnings Based Measures Of Retirement: When retirement status is measured by whether current earnings are less then 60 percent of the maximum earnings observed for the respondent, in wave 1 the earnings based measure indicates about the same proportion are not retired as does the hours based measure. However, the retirement flow from full time work is higher when using earnings based measures of retirement than when the hours based measures are used.

Differences In Retirement By Gender, Race And Ethnicity: We also found significant differences in retirement rates when we examined retirement by gender, race and ethnicity, although these differences vary with the definition of retirement. Whites are more likely to be not retired than Blacks or Hispanics. Most noticeable are some major differences in retirement outcomes reported by women and men. Using the self reported measure of retirement status, at any age, men are 3 to 12 percentage points more likely to be not retired than women, with the gap disappearing only at age 65 when less than a fifth of men or women are working full time. Men are 1 to 6 percentage points more likely to be working while partially retired than women through age 65 , with the difference increasing with age and becoming very large after 65 . Women are about 10 to 20 percentage points more likely than men to report that the retirement question is not relevant.

Dynamic Structure Of The Complex Retirement Measure: Our analysis of retirement dynamics was based on self reported retirement status. Among those transiting between the states of not 
retired, partially retired, completely retired and not relevant between the first four waves of the HRS, seventy one percent of the transitions were continuations, where the respondent reported not retired, partially retired, completely retired, or not relevant in two adjoining periods. Of the remaining twenty nine percent, about 17.4 percent of the transitions were in the direction of lowering work effort, moving from not retired toward retired, while a 6.1 percent of transitions were in the direction of increasing work effort, with the other 5.5 percent involving transitions between completely retired and not relevant.

Starting around age 53 the proportion of males not retired begins to decline at roughly three or four percentage points per year until after age 61. Between ages 61 and 62 the decline is about 20 percentage points, and from 62 to 63 the proportion not retired declines over two percentage points. There is a six percentage point decline from age 63 to 64 , and an eleven percentage point decline from age 64 to 65 . Only eighteen percentage points of males age 65 report themselves as not retired. Among men who report themselves as partially retired, partial retirement increases with age, where it exceeds a fifth of the population after age 65 .

The proportion of men who say they are fully retired, or that the retirement question is not relevant, rises with age, jumping 13 percentage points between ages 61 and 62 . Between 64 and 65 there is a 7 percentage point jump.

The decline for women in the percent not retired is evident from age 54. There is a 14 percentage point drop at age 61. At age 65 only 17 percent report they are not retired. Partial retirement rises with age to about 15 percentage points. The proportion of the sample answering that 
the retirement question is not relevant is three to four times as high for women than men and rises through the early 60s. By age 65, about 31 percent of the sample of women is working, 16 percentage points as not retired, and 14 percentage points as partially retired.

Retirement Outcome Changes Over Time: Lastly, we compared flows from full-time work between the Health and Retirement Study and the Retirement History Study, which reported retirement outcomes for the cohort born from 1906 to 1911 . The major trends to early retirement are readily apparent. At age 60, more than three fourths of the RHS was still working full time, compared to 61 percent of males in the HRS. The peak in the flow from full-time work in the RHS is at age 65, while in the HRS, about 11 percent are leaving full time work at age 65. On the other hand, the flow from full-time work at age 62 is more important for the HRS cohort.

A little more than a fifth of the HRS sample reports they were partially retired at least once in the first four waves. This is below the number found for the Retirement History Study, where roughly a third were found to have ever partially retired. But the HRS sample is much younger than the RHS sample, and many more will eventually transit through the state of partial retirement. Indeed, at all ages many more respondents report they are partially retired to the HRS than reported partial retirement to the RHS.

Although the importance of particular retirement flows have changed from the late 1970s, the retirement variable remains extremely complex: partial retirement continues to be very important; a large number of different retirement flows are observed across the first four waves of the HRS; measured retirement is seen to differ with the definition of retirement used, with the precise wording of 
questions, and among various groups analyzed. Given the complexity of the retirement variable, modeling the full set of retirement outcomes will remain a difficult challenge. 
Table 1: Alternative Definitions of Retirement

\begin{tabular}{|l|l|l|l|}
\hline \multirow{2}{*}{ Retirement Definition } & \multicolumn{2}{|c|}{ Retirement Status } & Completely Retired (R) \\
\cline { 2 - 4 } & Not Retired (F) & Partially Retired (P) & self explanatory \\
\hline Self Reported & self explanatory & self explanatory & not employed \\
\hline By Usual Hours/Weeks & $25+$ hours & $1-24$ hours & not employed \\
\hline By Usual Hours/Year & $1200+$ hours & $1-1199$ hours & not employed \\
\hline By Leaving 10+ Year Job & $\begin{array}{l}\text { still in } 10+\text { year job held after } \\
\text { age } 45\end{array}$ & working in another job & not employed \\
\hline By Leaving 20+ Year Job & $\begin{array}{l}\text { still in } 20+\text { year job held after } \\
\text { age 45 }\end{array}$ & working in another job & not employed \\
\hline By Hourly Wage & usual wage $60 \%+$ of maximum & usual wage <60\% of maximum & not employed \\
\hline By Weekly Earnings & $\begin{array}{l}\text { usual earnings } 60 \%+\text { of } \\
\text { maximum }\end{array}$ & $\begin{array}{l}\text { usual earnings <60\% of } \\
\text { maximum }\end{array}$ & not relevant \\
\hline By Social Security Receipt & not received social security & & received social security \\
\hline \hline
\end{tabular}


Table 2: Retirement Outcomes By Wave Under Alternative Definitions of Retirement

\begin{tabular}{|c|c|c|c|c|c|c|c|c|c|c|c|c|c|c|c|c|}
\hline \multirow{3}{*}{ Retirement Measure } & \multicolumn{12}{|c|}{ Retirement Status } & \multirow{2}{*}{\multicolumn{4}{|c|}{ Sample Size With Complete Data }} \\
\hline & \multicolumn{4}{|c|}{ Not Retired (F) } & \multicolumn{4}{|c|}{ Partially Retired (P) } & \multicolumn{4}{|c|}{ Completely Retired (R) } & & & & \\
\hline & $\begin{array}{l}\text { Wav } \\
\text { e } 1\end{array}$ & $\begin{array}{l}\text { Wav } \\
\text { e } 2\end{array}$ & $\begin{array}{l}\text { Wav } \\
\text { e } 3\end{array}$ & $\begin{array}{c}\text { Wave } \\
4\end{array}$ & $\begin{array}{l}\text { Wav } \\
\text { e } 1\end{array}$ & $\begin{array}{c}\text { Wave } \\
2\end{array}$ & $\begin{array}{l}\text { Wav } \\
\text { e } 3\end{array}$ & $\begin{array}{l}\text { Wav } \\
\text { e } 4\end{array}$ & $\begin{array}{l}\text { Wav } \\
\text { e } 1\end{array}$ & $\begin{array}{l}\text { Wav } \\
\text { e } 2\end{array}$ & $\begin{array}{l}\text { Wav } \\
\text { e } 3\end{array}$ & $\begin{array}{c}\text { Wave } \\
4\end{array}$ & $\begin{array}{l}\text { Wav } \\
\text { e } 1\end{array}$ & $\begin{array}{c}\text { Wave } \\
2\end{array}$ & $\begin{array}{l}\text { Wav } \\
\text { e } 3\end{array}$ & $\begin{array}{c}\text { Wave } \\
4\end{array}$ \\
\hline Self Reported & 71.5 & 63.6 & 51.6 & 42.3 & 6.3 & 10.0 & 11.9 & 12.7 & 12.3 & 19.1 & 24.7 & 27.3 & 9297 & 8265 & 7828 & 7307 \\
\hline By Usual Hours/Weeks & 61.9 & 55.8 & 47.7 & 41.0 & 7.0 & 7.6 & 9.3 & 9.9 & 31.1 & 36.6 & 43.0 & 49.0 & 9297 & 8233 & 7806 & 7266 \\
\hline By Usual Hours/Year & 60.1 & 55.0 & 46.8 & 40.0 & 8.1 & 8.2 & 9.9 & 10.6 & 31.8 & 36.8 & 43.3 & 49.4 & 9297 & 8188 & 7761 & 7221 \\
\hline By Leaving $10+$ Year Job & 59.9 & 49.4 & 37.7 & 28.4 & 21.7 & 23.2 & 25.8 & 26.0 & 18.3 & 27.4 & 36.5 & 45.6 & 5204 & 4483 & 4014 & 3612 \\
\hline By Leaving 20+ Year Job & 63.8 & 51.4 & 38.4 & 27.6 & 17.9 & 19.6 & 23.2 & 23.6 & 18.2 & 28.9 & 38.4 & 48.8 & 2720 & 2321 & 2048 & 1825 \\
\hline By Hourly Wage & 57.7 & 48.6 & 42.0 & 35.9 & 9.9 & 11.6 & 11.8 & 11.8 & 32.3 & 39.8 & 46.1 & 52.3 & 9172 & 7579 & 7268 & 6795 \\
\hline By Weekly Earnings & 56.1 & 46.3 & 39.0 & 33.1 & 11.5 & 13.9 & 14.6 & 14.5 & 32.3 & 39.8 & 46.1 & 52.3 & 9172 & 7579 & 7268 & 6795 \\
\hline $\begin{array}{l}\text { By Social Security } \\
\text { Receipt }\end{array}$ & 94.9 & 86.4 & 73.3 & 60.0 & n.a. & .n.a. & n.a. & n.a. & 5.1 & 13.6 & 26.7 & 40.0 & 9226 & 8185 & 7788 & 7265 \\
\hline
\end{tabular}

Source: Authors' calculations. Definitions of retirement outcomes are presented in Table 1. Sample exclusions for each table and wave are reported in Appendix 1. All results are weighted using the weights from wave1. Percentages not retired, partially retired and fully retired do not sum to 1.0 due to inclusion of those answering not relevant in the population base. 
Table 3: Percent Not Retired By Gender, Race and Ethnicity

\begin{tabular}{|c|c|c|c|c|c|c|c|c|c|c|c|c|c|c|c|c|}
\hline \multirow{2}{*}{$\begin{array}{l}\text { Percent Not } \\
\text { Retired }\end{array}$} & \multicolumn{4}{|c|}{ Self Reported } & \multicolumn{4}{|c|}{ Usual Hours Per Year } & \multicolumn{4}{|c|}{ Weekly Earnings } & \multicolumn{4}{|c|}{ Social Security Receipt } \\
\hline & $\begin{array}{l}\text { Wav } \\
\text { e } 1\end{array}$ & $\begin{array}{l}\text { Wav } \\
\text { e } 2\end{array}$ & $\begin{array}{l}\text { Wav } \\
\text { e } 3\end{array}$ & $\begin{array}{l}\text { Wav } \\
\text { e } 4\end{array}$ & $\begin{array}{l}\text { Wav } \\
\text { e } 1\end{array}$ & $\begin{array}{l}\text { Wav } \\
\text { e } 2\end{array}$ & $\begin{array}{l}\text { Wav } \\
\text { e } 3\end{array}$ & $\begin{array}{l}\text { Wav } \\
\text { e } 4\end{array}$ & $\begin{array}{c}\text { Wav } \\
\text { e } 1\end{array}$ & $\begin{array}{l}\text { Wav } \\
\text { e } 2\end{array}$ & $\begin{array}{c}\text { Wav } \\
\text { e } 3\end{array}$ & $\begin{array}{c}\text { Wav } \\
\text { e } 4\end{array}$ & $\begin{array}{c}\text { Wave } \\
1\end{array}$ & $\begin{array}{l}\text { Wav } \\
\text { e } 2\end{array}$ & $\begin{array}{c}\text { Wav } \\
\text { e } 3\end{array}$ & $\begin{array}{c}\text { Wav } \\
\text { e } 4\end{array}$ \\
\hline All & 71.5 & 63.6 & 51.6 & 42.3 & 60.1 & 55.0 & 46.8 & 40.0 & 56.1 & 46.3 & 39.2 & 33.1 & 94.9 & 86.4 & 73.3 & 60.0 \\
\hline Males & 77.1 & 67.0 & 56.2 & 46.8 & 72.2 & 66.3 & 57.5 & 49.4 & 62.4 & 53.0 & 45.4 & 38.3 & 94.8 & 86.9 & 74.8 & 62.8 \\
\hline Females & 66.6 & 60.8 & 47.7 & 38.7 & 49.6 & 45.7 & 38.1 & 32.5 & 50.7 & 40.8 & 34.2 & 29.1 & 95.0 & 85.9 & 72.0 & 57.8 \\
\hline All Whites & 72.4 & 64.3 & 51.7 & 42.1 & 61.6 & 56.4 & 47.7 & 40.3 & 57.0 & 47.3 & 39.4 & 33.2 & 95.4 & 86.7 & 73.3 & 59.8 \\
\hline White Males & 78.0 & 67.8 & 56.7 & 46.7 & 74.3 & 68.1 & 58.5 & 49.7 & 63.7 & 54.2 & 45.7 & 38.5 & 95.2 & 87.1 & 75.1 & 62.8 \\
\hline White Females & 67.4 & 61.2 & 47.4 & 38.4 & 50.4 & 46.5 & 38.4 & 32.5 & 51.1 & 41.6 & 34.3 & 29.0 & 95.5 & 86.4 & 71.8 & 57.3 \\
\hline All Blacks & 66.0 & 58.2 & 48.8 & 41.3 & 53.2 & 46.9 & 42.5 & 36.7 & 52.7 & 40.7 & 37.1 & 30.8 & 91.8 & 82.7 & 71.7 & 59.7 \\
\hline Black Males & 67.6 & 57.7 & 50.2 & 42.1 & 58.7 & 51.3 & 50.1 & 43.5 & 51.7 & 42.0 & 39.3 & 33.2 & 91.6 & 83.6 & 71.8 & 59.9 \\
\hline Black Females & 64.9 & 58.6 & 47.9 & 40.8 & 49.2 & 44.0 & 37.5 & 32.6 & 53.4 & 39.8 & 35.6 & 29.3 & 91.9 & 82.1 & 71.7 & 59.5 \\
\hline All Hispanics & 67.9 & 59.9 & 49.3 & 43.4 & 50.2 & 46.0 & 38.3 & 37.6 & 48.2 & 39.9 & 36.6 & 32.6 & 93.3 & 86.8 & 76.1 & 63.2 \\
\hline Hispanic Males & 78.6 & 67.6 & 53.7 & 52.4 & 65.7 & 61.2 & 51.4 & 51.0 & 59.3 & 52.9 & 48.9 & 40.9 & 92.8 & 88.0 & 75.3 & 65.3 \\
\hline Hispanic Females & 58.8 & 53.8 & 45.8 & 36.5 & 37.0 & 34.2 & 28.3 & 27.2 & 38.6 & 30.2 & 27.6 & 26.1 & 93.7 & 85.9 & 76.8 & 61.6 \\
\hline
\end{tabular}

See Table 2 for sample sizes and definitions. 
Table 4A: Retirement States Between Adjoining Waves, Self Reported Data, Including Not Relevant and Not Available Responses

\begin{tabular}{|c|c|c|c|c|c|c|}
\hline \multirow[t]{2}{*}{ Final State } & \multicolumn{3}{|c|}{ Initial State } & & & \multirow[t]{2}{*}{ Row Total } \\
\hline & Not Retired & Partially Retired & Completely Retired & Ques. Not Relevant & Not Available & \\
\hline Not Retired & 0.383 & 0.014 & 0.004 & 0.014 & 0.014 & 0.429 \\
\hline Partially Retired & 0.041 & 0.034 & 0.012 & 0.004 & 0.003 & 0.094 \\
\hline Completely Retired & 0.048 & 0.019 & 0.101 & 0.017 & 0.005 & 0.190 \\
\hline Ques. Not Relevant & 0.022 & 0.007 & 0.026 & 0.039 & 0.004 & 0.098 \\
\hline Not Available & 0.055 & 0.007 & 0.018 & 0.010 & 0.100 & 0.190 \\
\hline$\overline{~ C o l u m n ~ T o t a l ~}$ & 0.549 & $\overline{0.081}$ & 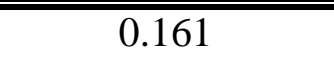 & $\overline{0.084}$ & 0.126 & $\bar{~} 1.001$ \\
\hline
\end{tabular}

*Each cell indicates the proportion of the entire sample falling in the indicated category. The not available category includes refusals, don't knows, proxies, and people who were not interviewed on that wave. See Appendix 1 for sample exclusions.

Table 4B: Retirement States Between Adjoining Waves, Self Reported Data, Including Not Relevant Responses

\begin{tabular}{|c|c|c|c|c|c|}
\hline \multirow{2}{*}{ Final State } & \multicolumn{3}{|c|}{ Initial State } & & \multirow{2}{*}{ Row Total } \\
\hline & Not Retired & Partially Retired & Completely Retired & Ques. Not Relevant & \\
\hline Not Retired & 0.488 & 0.018 & 0.005 & 0.018 & 0.529 \\
\hline Partially Retired & 0.052 & 0.043 & 0.015 & 0.005 & 0.115 \\
\hline Completely Retired & 0.061 & 0.024 & 0.129 & 0.022 & 0.236 \\
\hline Ques. Not Relevant & 0.028 & 0.009 & 0.033 & 0.050 & 0.120 \\
\hline Column Total & 0.629 & 0.09 & 0.182 & 0.095 & 1.000 \\
\hline
\end{tabular}


Table 5: Entry Rates Into Indicated States

\begin{tabular}{|l|ccccc||}
\hline \multirow{2}{*}{ Final State } & \multicolumn{5}{|c|}{ Initial State } \\
\cline { 2 - 6 } & Not Retired & Partially Retired & Completely Retired & Ques. Not Relevant & Not Available \\
\hline Not Retired & 0.892 & 0.034 & 0.010 & 0.032 & 0.033 \\
Partially Retired & 0.437 & 0.361 & 0.128 & 0.045 & 0.028 \\
Completely Retired & 0.253 & 0.100 & 0.531 & 0.088 & 0.028 \\
Ques. Not & 0.228 & 0.067 & 0.261 & 0.402 & 0.042 \\
Relevant & 0.290 & 0.038 & 0.093 & 0.055 & 1 \\
Not Available & & & 0.525 \\
\hline
\end{tabular}

*The not available category includes refusals, don't knows, proxies, and people who were not interviewed on that wave. See Appendix 1 for sample exclusions. 
Table 6: Exit Rates From Indicated States

\begin{tabular}{|c|c|c|c|c|c|}
\hline \multirow[t]{2}{*}{ Final State } & \multicolumn{5}{|c|}{ Initial State } \\
\hline & Not Retired & Partially Retired & Completely Retired & Ques. Not Relevant & Not Available \\
\hline Not Retired & 0.697 & 0.178 & 0.025 & 0.163 & 0.111 \\
\hline Partially Retired & 0.074 & 0.416 & 0.074 & 0.050 & 0.020 \\
\hline $\begin{array}{l}\text { Completely - } \\
\text { Retired }\end{array}$ & 0.088 & 0.236 & 0.631 & 0.199 & 0.043 \\
\hline Ques. Not Relevant & 0.041 & 0.081 & 0.159 & 0.465 & 0.032 \\
\hline Not Available & 0.099 & 0.089 & 0.110 & 0.123 & 0.793 \\
\hline Sum & 0.999 & 1 & 0.999 & 1 & 0.999 \\
\hline
\end{tabular}

*The not available category includes refusals, don't knows, proxies, and people who were not interviewed on that wave. See Appendix 1 for sample exclusions. 
Table 7: Self Reported Retirement Status By Wave (Not Retired in Wave 1)

\begin{tabular}{|c|c|c|c|c|c|}
\hline \multirow{2}{*}{$\begin{array}{c}\text { Status in Waves } 3 \\
\text { and } 4\end{array}$} & \multicolumn{5}{|c|}{ Status in Wave 2} \\
\hline & Not Retired $(\mathrm{F})$ & Partially Retired (P) & Completely Retired (R) & Ouestion Not Relevant (X) & Not Available (.) \\
\hline $\mathrm{FF}$ & 24.66 & 0.43 & 0.05 & 0.34 & 1.11 \\
\hline FP & 2.56 & 0.22 & 0.07 & 0.06 & 0.06 \\
\hline FR & 3.79 & 0.12 & 0.02 & 0.05 & 0.05 \\
\hline FX & 0.96 & 0.09 & 0.02 & 0.06 & 0.02 \\
\hline $\mathrm{F}$. & 3.17 & 0.01 & 0.00 & 0.09 & 0.41 \\
\hline PF & 0.68 & 0.34 & 0.02 & 0.02 & 0.03 \\
\hline PP & 1.74 & 0.73 & 0.15 & 0.02 & 0.08 \\
\hline PR & 0.96 & 0.34 & 0.12 & 0.02 & 0.01 \\
\hline PX & 0.23 & 0.04 & 0.05 & 0.04 & \\
\hline P. & 0.29 & 0.13 & 0.03 & 0.01 & 0.05 \\
\hline $\mathrm{RF}$ & 0.15 & 0.05 & 0.03 & 0.01 & \\
\hline $\mathrm{RP}$ & 0.45 & 0.16 & 0.22 & & 0.04 \\
\hline $\mathrm{RR}$ & 3.01 & 0.56 & 2.08 & 0.16 & 0.18 \\
\hline $\mathrm{RX}$ & 0.67 & 0.18 & 0.66 & 0.13 & 0.07 \\
\hline $\mathrm{R}$. & 0.38 & 0.12 & 0.38 & 0.02 & 0.07 \\
\hline $\mathrm{XF}$ & 0.38 & 0.01 & 0.01 & 0.04 & 0.02 \\
\hline XP & 0.09 & 0.04 & 0.02 & 0.02 & \\
\hline $\mathrm{XR}$ & 0.20 & 0.07 & 0.14 & 0.10 & 0.05 \\
\hline $\mathrm{XX}$ & 0.85 & 0.12 & 0.17 & 0.47 & 0.07 \\
\hline $\mathrm{X}$. & 0.15 & 0.00 & 0.09 & 0.06 & 0.08 \\
\hline.$F$ & 0.83 & 0.01 & 0.01 & & 0.35 \\
\hline.$P$ & 0.10 & 0.02 & 0.01 & 0.01 & 0.08 \\
\hline . R & 0.14 & 0.05 & 0.04 & 0.01 & 0.18 \\
\hline.$X$ & 0.19 & 0.01 & 0.03 & 0.02 & 0.08 \\
\hline.. & 3.36 & 0.30 & 0.42 & 0.18 & 4.17 \\
\hline Sum of Column & 49.99 & 4.15 & 4.84 & 1.94 & 7.26 \\
\hline
\end{tabular}

*The not available category includes refusals, don't knows, proxies, and those not interviewed on that wave. See Appendix 1 for sample exclusions. 
Table 7: Continued

(Partially Retired in Wave 1)

\begin{tabular}{|c|c|c|c|c|c|}
\hline \multirow{2}{*}{$\begin{array}{c}\text { Status in Waves } 3 \\
\text { and } 4\end{array}$} & \multicolumn{5}{|c|}{ Status in Wave 2} \\
\hline & Not Retired & Partially Retired & Completely Retired & Question Not Relevant & Not Available \\
\hline FF & 0.26 & 0.20 & 0.03 & 0.01 & \\
\hline FP & 0.05 & 0.19 & 0.01 & & 0.01 \\
\hline FR & 0.07 & 0.03 & 0.03 & 0.02 & 0.01 \\
\hline FX & 0.04 & 0.05 & 0.03 & 0.01 & 0.00 \\
\hline F. & 0.08 & 0.05 & & & 0.01 \\
\hline $\mathrm{PF}$ & 0.08 & 0.13 & 0.01 & 0.01 & \\
\hline PP & 0.19 & 0.75 & 0.07 & 0.01 & 0.01 \\
\hline PR & 0.05 & 0.25 & 0.07 & 0.01 & 0.01 \\
\hline PX & 0.05 & 0.05 & 0.04 & & 0.01 \\
\hline P. & 0.03 & 0.06 & 0.01 & & 0.03 \\
\hline $\mathrm{RF}$ & & 0.01 & 0.00 & 0.03 & \\
\hline $\mathrm{RP}$ & 0.01 & 0.13 & 0.04 & 0.02 & \\
\hline $\mathrm{RR}$ & 0.12 & 0.27 & 0.49 & 0.05 & 0.04 \\
\hline $\mathrm{RX}$ & 0.02 & 0.10 & 0.22 & 0.02 & \\
\hline $\mathrm{R}$. & 0.02 & 0.04 & 0.05 & & 0.02 \\
\hline $\mathrm{XF}$ & 0.00 & & 0.01 & 0.01 & \\
\hline $\mathrm{XP}$ & 0.01 & 0.01 & 0.02 & 0.01 & \\
\hline $\mathrm{XR}$ & 0.00 & 0.01 & 0.05 & 0.01 & \\
\hline $\mathrm{XX}$ & & 0.05 & 0.07 & 0.03 & \\
\hline $\mathrm{X}$. & 0.01 & 0.01 & 0.03 & & \\
\hline.$F$ & 0.01 & & & & \\
\hline.$P$ & 0.01 & 0.03 & & & \\
\hline . R & 0.01 & 0.01 & 0.01 & & 0.03 \\
\hline.$X$ & & 0.02 & & & 0.02 \\
\hline .. & 0.09 & 0.12 & 0.12 & 0.02 & 0.40 \\
\hline Sum of Column & 1.21 & 2.58 & 1.41 & 0.27 & 0.60 \\
\hline
\end{tabular}

*The not available category includes refusals, don't knows, proxies, and those not interviewed on that wave. See Appendix 1 for sample exclusions. 
Table 7: Continued

(Completely Retired in Wave 1)

\begin{tabular}{|c|c|c|c|c|c|}
\hline \multirow{2}{*}{$\begin{array}{c}\text { Status in Waves } 3 \\
\text { and } 4\end{array}$} & \multicolumn{5}{|c|}{ Status in Wave 2} \\
\hline & Not Retired & Partially Retired & Completely Retired & Question Not Relevant & Not Available \\
\hline $\mathrm{FF}$ & 0.04 & 0.03 & & & \\
\hline FP & 0.02 & 0.05 & & & 0.01 \\
\hline FR & 0.04 & 0.01 & 0.04 & & 0.00 \\
\hline $\mathrm{FX}$ & 0.01 & & 0.05 & 0.02 & 0.01 \\
\hline F. & 0.02 & 0.01 & 0.02 & & \\
\hline $\mathrm{PF}$ & 0.01 & 0.00 & 0.08 & & \\
\hline PP & 0.01 & 0.15 & 0.13 & 0.01 & \\
\hline PR & & 0.06 & 0.15 & & \\
\hline PX & 0.02 & 0.03 & 0.10 & 0.01 & \\
\hline P. & 0.01 & 0.04 & 0.01 & 0.01 & \\
\hline $\mathrm{RF}$ & 0.01 & & 0.04 & & 0.01 \\
\hline $\mathrm{RP}$ & & 0.09 & 0.15 & 0.01 & 0.01 \\
\hline $\mathrm{RR}$ & 0.03 & 0.20 & 3.46 & 0.12 & 0.09 \\
\hline $\mathrm{RX}$ & 0.02 & 0.09 & 1.31 & 0.08 & 0.02 \\
\hline $\mathrm{R}$. & & 0.06 & 0.61 & 0.04 & 0.01 \\
\hline $\mathrm{XF}$ & & & 0.02 & 0.01 & \\
\hline $\mathrm{XP}$ & 0.01 & 0.01 & & 0.01 & \\
\hline $\mathrm{XR}$ & 0.01 & 0.04 & 0.47 & 0.06 & 0.02 \\
\hline$X X$ & 0.09 & 0.02 & 0.28 & 0.24 & 0.05 \\
\hline $\mathrm{X}$ & & 0.00 & 0.11 & 0.08 & 0.05 \\
\hline.$F$ & & & & & 0.01 \\
\hline.$P$ & & & & & 0.01 \\
\hline . R & & 0.01 & 0.05 & & 0.07 \\
\hline.$X$ & & 0.01 & 0.03 & 0.00 & 0.02 \\
\hline .. & 0.05 & 0.13 & 0.86 & 0.16 & 1.05 \\
\hline Sum of Column & 0.40 & 1.04 & 7.97 & 0.86 & 1.44 \\
\hline
\end{tabular}

*The not available category includes refusals, don't knows, proxies, and those not interviewed on that wave. See Appendix 1 for sample exclusions. 
Table 7: Continued

(Question Not Relevant in Wave 1)

\begin{tabular}{|c|c|c|c|c|c|}
\hline \multirow{2}{*}{$\begin{array}{c}\text { Status in Waves } 3 \\
\text { and } 4\end{array}$} & \multicolumn{5}{|c|}{ Status in Wave 2} \\
\hline & Not Retired & Partially Retired & Completely Retired & Question Not Relevant & Not Available \\
\hline $\mathrm{FF}$ & 0.28 & 0.07 & 0.04 & 0.05 & 0.05 \\
\hline FP & 0.03 & 0.01 & & 0.02 & \\
\hline FR & 0.03 & & 0.02 & 0.02 & \\
\hline $\mathrm{FX}$ & 0.30 & 0.02 & 0.01 & 0.15 & 0.01 \\
\hline F. & 0.05 & & 0.01 & 0.02 & \\
\hline $\mathrm{PF}$ & 0.04 & 0.02 & 0.01 & 0.00 & \\
\hline $\mathrm{PP}$ & 0.03 & 0.04 & & 0.01 & \\
\hline PR & 0.04 & & 0.02 & 0.02 & 0.01 \\
\hline PX & 0.09 & 0.09 & 0.04 & 0.05 & 0.01 \\
\hline P. & & & 0.02 & & \\
\hline $\mathrm{RF}$ & & & 0.02 & 0.02 & \\
\hline $\mathrm{RP}$ & & & 0.03 & 0.01 & 0.01 \\
\hline $\mathrm{RR}$ & 0.08 & 0.02 & 0.34 & 0.22 & 0.03 \\
\hline $\mathrm{RX}$ & 0.19 & 0.08 & 0.37 & 0.21 & \\
\hline R. & 0.01 & & 0.10 & 0.07 & \\
\hline $\mathrm{XF}$ & 0.11 & 0.01 & 0.02 & 0.12 & 0.01 \\
\hline $\mathrm{XP}$ & 0.01 & 0.01 & & 0.05 & \\
\hline $\mathrm{XR}$ & 0.13 & 0.06 & 0.17 & 0.18 & 0.01 \\
\hline XX & 0.71 & 0.19 & 0.43 & 1.39 & 0.10 \\
\hline $\mathrm{X}$. & 0.09 & 0.04 & 0.16 & 0.25 & 0.06 \\
\hline.$F$ & & 0.01 & 0.02 & 0.01 & \\
\hline.$P$ & & 0.01 & & & 0.01 \\
\hline . R & & & 0.03 & 0.01 & \\
\hline.$X$ & 0.00 & & 0.02 & 0.05 & 0.05 \\
\hline .. & 0.14 & 0.04 & 0.11 & 0.23 & 0.73 \\
\hline Sum of Column & 2.36 & 0.72 & 1.99 & 3.16 & 1.09 \\
\hline
\end{tabular}

*The not available category includes refusals, don't knows, proxies, and those not interviewed on that wave. See Appendix 1 for sample exclusions. 
Table 7: Continue

(Not Available in Wave 1)

\begin{tabular}{|c|c|c|c|c|c|}
\hline \multirow{2}{*}{$\begin{array}{c}\text { Status in Waves } 3 \\
\text { and } 4\end{array}$} & \multicolumn{5}{|c|}{ Status in Wave 2} \\
\hline & Not Retired & Partially Retired & Completely Retired & Question Not Relevant & Not Available \\
\hline FF & 0.20 & 0.01 & & & 0.23 \\
\hline FP & 0.01 & & & & 0.02 \\
\hline FR & 0.01 & & & & 0.04 \\
\hline $\mathrm{FX}$ & 0.01 & & & & 0.01 \\
\hline $\mathrm{F}$. & 0.02 & & & & 0.16 \\
\hline $\mathrm{PF}$ & 0.01 & & & & \\
\hline $\mathrm{PP}$ & 0.03 & 0.01 & 0.01 & & 0.06 \\
\hline PR & & & & & 0.02 \\
\hline PX & 0.03 & & & & \\
\hline P. & & 0.01 & & & 0.05 \\
\hline $\mathrm{RF}$ & 0.01 & & & & \\
\hline $\mathrm{RP}$ & 0.01 & & & & \\
\hline $\mathrm{RR}$ & 0.02 & 0.02 & 0.03 & & 0.06 \\
\hline $\mathrm{RX}$ & & & 0.04 & 0.01 & 0.00 \\
\hline $\mathrm{R}$. & & & 0.02 & & 0.07 \\
\hline $\mathrm{XF}$ & & & & & 0.02 \\
\hline $\mathrm{XP}$ & & & & & \\
\hline $\mathrm{XR}$ & & & & & 0.01 \\
\hline $\mathrm{XX}$ & 0.03 & 0.01 & 0.01 & & 0.02 \\
\hline $\mathrm{X}$. & & & & & 0.02 \\
\hline.$F$ & 0.05 & & & & 0.12 \\
\hline.$P$ & 0.02 & & & & 0.02 \\
\hline R & & & & & 0.11 \\
\hline.$X$ & & & & & 0.05 \\
\hline.. & 0.10 & & & & 2.82 \\
\hline Sum of Column & 0.56 & 0.06 & 0.11 & 0.01 & 3.91 \\
\hline
\end{tabular}

\footnotetext{
*The not available category includes refusals, don't knows, proxies, and not interviewed on that wave. See Appendix 1 for sample exclusions.
} 
Table 8: Retirement Outcomes By Age

Panel A: Proportion of Males At Indicated Age Falling In Each Cell

\begin{tabular}{|c|c|c|c|c|}
\hline \multirow[t]{2}{*}{ Age } & \multicolumn{4}{|c|}{ Self Reported Retirement Status } \\
\hline & Not Retired & Partially Retired & Completely Retired & Ques. Not Relevant \\
\hline 50 & 0.851 & 0.033 & 0.086 & 0.030 \\
\hline 51 & 0.865 & 0.053 & 0.053 & 0.028 \\
\hline 52 & 0.855 & 0.064 & 0.051 & 0.030 \\
\hline 53 & 0.848 & 0.055 & 0.062 & 0.035 \\
\hline 54 & 0.817 & 0.071 & 0.085 & 0.028 \\
\hline 55 & 0.785 & 0.083 & 0.095 & 0.037 \\
\hline 56 & 0.744 & 0.098 & 0.122 & 0.036 \\
\hline 57 & 0.726 & 0.098 & 0.138 & 0.038 \\
\hline 58 & 0.686 & 0.104 & 0.167 & 0.043 \\
\hline 59 & 0.657 & 0.120 & 0.182 & 0.041 \\
\hline 60 & 0.610 & 0.120 & 0.232 & 0.038 \\
\hline 61 & 0.571 & 0.129 & 0.250 & 0.049 \\
\hline 62 & 0.374 & 0.192 & 0.382 & 0.052 \\
\hline 63 & 0.353 & 0.198 & 0.392 & 0.057 \\
\hline 64 & 0.295 & 0.185 & 0.464 & 0.056 \\
\hline 65 & 0.184 & 0.225 & 0.523 & 0.068 \\
\hline 66 & 0.184 & 0.223 & 0.507 & 0.086 \\
\hline 67 & 0.126 & 0.327 & 0.384 & 0.162 \\
\hline
\end{tabular}

See Appendix 1 for sample exclusions. 
Panel B: Proportion of Females At Indicated Age In Each Cell

\begin{tabular}{|c|c|c|c|c|}
\hline \multirow[t]{2}{*}{ Age } & \multicolumn{4}{|c|}{ Self Reported Retirement Status } \\
\hline & Not Retired & Partially Retired & Completely Retired & Ques. Not Relevant \\
\hline 50 & 0.840 & 0.029 & 0.037 & 0.093 \\
\hline 51 & 0.772 & 0.037 & 0.062 & 0.129 \\
\hline 52 & 0.759 & 0.049 & 0.051 & 0.141 \\
\hline 53 & 0.763 & 0.035 & 0.082 & 0.120 \\
\hline 54 & 0.717 & 0.054 & 0.091 & 0.137 \\
\hline 55 & 0.698 & 0.054 & 0.102 & 0.146 \\
\hline 56 & 0.641 & 0.065 & 0.119 & 0.175 \\
\hline 57 & 0.651 & 0.067 & 0.117 & 0.166 \\
\hline 58 & 0.582 & 0.084 & 0.156 & 0.177 \\
\hline 59 & 0.581 & 0.078 & 0.173 & 0.168 \\
\hline 60 & 0.496 & 0.094 & 0.223 & 0.187 \\
\hline 61 & 0.485 & 0.095 & 0.248 & 0.172 \\
\hline 62 & 0.341 & 0.129 & 0.355 & 0.175 \\
\hline 63 & 0.279 & 0.134 & 0.383 & 0.204 \\
\hline 64 & 0.217 & 0.149 & 0.395 & 0.239 \\
\hline 65 & 0.166 & 0.145 & 0.496 & 0.193 \\
\hline 66 & 0.111 & 0.141 & 0.464 & 0.284 \\
\hline 67 & 0.115 & 0.063 & 0.420 & 0.403 \\
\hline
\end{tabular}

Notes: See Panel A. 
Table 9: Retirement Status By Age In Selected Years, Including Question Not Relevant and Not Available Responses Panel A: Proportion of Males At Each Age In Each Cell

\begin{tabular}{|c|c|c|c|c|c|c|c|c|c|c|c|c|c|c|c|c|c|c|c|c|}
\hline \multirow[t]{2}{*}{ Age } & \multicolumn{4}{|c|}{ Not Retired } & \multicolumn{4}{|c|}{ Partially Retired } & \multicolumn{4}{|c|}{ Completely Retired } & \multicolumn{4}{|c|}{ Ques. Not Relevant } & \multicolumn{4}{|c|}{ Not Available } \\
\hline & W 1 & W 2 & W 3 & W4 & W 1 & W 2 & W 3 & W 4 & W 1 & W 2 & W 3 & W 4 & W 1 & W 2 & W 3 & W 4 & W 1 & W 2 & W 3 & W 4 \\
\hline 50 & 0.801 & & & & 0.031 & & & & 0.081 & & & & 0.028 & & & & 0.059 & & & \\
\hline 51 & 0.811 & & & & 0.050 & & & & 0.050 & & & & 0.026 & & & & 0.062 & & & \\
\hline 52 & 0.799 & 0.764 & & & 0.059 & 0.059 & & & 0.047 & 0.049 & & & 0.031 & 0.017 & & & 0.064 & 0.111 & & \\
\hline 53 & 0.783 & 0.740 & & & 0.043 & 0.056 & & & 0.044 & 0.069 & & & 0.033 & 0.031 & & & 0.098 & 0.104 & & \\
\hline 54 & 0.765 & 0.716 & 0.757 & & 0.046 & 0.081 & 0.069 & & 0.072 & 0.092 & 0.048 & & 0.031 & 0.022 & 0.014 & & 0.086 & 0.089 & 0.111 & \\
\hline 55 & 0.725 & 0.679 & 0.708 & & 0.054 & 0.087 & 0.083 & & 0.106 & 0.062 & 0.087 & & 0.018 & 0.031 & 0.051 & & 0.097 & 0.141 & 0.071 & \\
\hline 56 & 0.735 & 0.661 & 0.645 & 0.664 & 0.078 & 0.081 & 0.116 & 0.079 & 0.104 & 0.135 & 0.115 & 0.063 & 0.025 & 0.016 & $\overline{0.042}$ & 0.066 & 0.058 & 0.107 & 0.082 & 0.128 \\
\hline 57 & 0.698 & 0.614 & 0.651 & 0.627 & 0.074 & 0.079 & 0.104 & 0.093 & 0.128 & 0.145 & 0.103 & 0.119 & 0.019 & 0.022 & 0.032 & 0.065 & 0.081 & 0.140 & 0.109 & 0.096 \\
\hline 58 & 0.622 & 0.635 & 0.605 & 0.602 & 0.089 & 0.089 & 0.105 & 0.091 & 0.165 & 0.158 & 0.155 & 0.118 & 0.026 & 0.016 & 0.056 & 0.063 & 0.097 & $\overline{0.102}$ & 0.079 & 0.126 \\
\hline 59 & 0.619 & 0.590 & 0.602 & 0.541 & 0.113 & 0.102 & 0.073 & 0.139 & 0.180 & 0.172 & 0.178 & 0.122 & 0.018 & 0.020 & 0.042 & 0.067 & 0.070 & 0.116 & 0.106 & 0.131 \\
\hline 60 & 0.634 & 0.493 & 0.525 & 0.531 & 0.093 & 0.105 & 0.130 & 0.106 & 0.199 & 0.241 & 0.211 & 0.183 & 0.012 & 0.021 & 0.050 & 0.059 & 0.062 & 0.141 & 0.084 & 0.121 \\
\hline 61 & 0.547 & 0.481 & 0.526 & 0.514 & 0.111 & 0.129 & 0.121 & 0.103 & 0.267 & 0.237 & 0.212 & 0.195 & 0.025 & 0.043 & 0.046 & 0.062 & 0.050 & 0.109 & 0.096 & 0.126 \\
\hline 62 & & 0.373 & 0.318 & 0.298 & & 0.169 & 0.180 & 0.162 & & 0.353 & 0.324 & 0.338 & & 0.016 & 0.054 & 0.074 & & 0.089 & 0.124 & 0.128 \\
\hline 63 & & 0.344 & 0.290 & 0.324 & & 0.158 & 0.215 & 0.150 & & 0.385 & 0.385 & 0.295 & & 0.014 & 0.038 & 0.081 & & 0.100 & 0.071 & 0.145 \\
\hline 64 & & & 0.267 & 0.257 & & & 0.156 & 0.173 & & & 0.455 & 0.367 & & & 0.024 & 0.077 & & & 0.097 & 0.126 \\
\hline 65 & & & 0.149 & 0.174 & & & 0.245 & 0.175 & & & 0.474 & 0.464 & & & 0.019 & 0.086 & & & 0.113 & 0.101 \\
\hline 66 & & & & 0.168 & & & & 0.203 & & & & 0.463 & & & & 0.078 & & & & 0.088 \\
\hline 67 & & & & 0.113 & & & & 0.294 & & & & 0.345 & & & & 0.146 & & & & 0.102 \\
\hline
\end{tabular}

See Appendix 1 for sample exclusions. 
Table 9, Panel B: Proportion of Females In Each Cell

\begin{tabular}{|c|c|c|c|c|c|c|c|c|c|c|c|c|c|c|c|c|c|c|c|c|}
\hline \multirow[t]{2}{*}{ Age } & \multicolumn{4}{|c|}{ Not Retired } & \multicolumn{4}{|c|}{ Partially Retired } & \multicolumn{4}{|c|}{ Completely Retired } & \multicolumn{4}{|c|}{ Ques. Not Relevant } & \multicolumn{4}{|c|}{ Not Available } \\
\hline & W 1 & W 2 & W 3 & W 4 & W 1 & W 2 & W 3 & W 4 & W 1 & W 2 & W 3 & W4 & W 1 & W 2 & W 3 & W 4 & W 1 & W 2 & W 3 & W 4 \\
\hline 50 & $\overline{0.840}$ & & & & 0.029 & & & & 0.037 & & & & 0.093 & & & & 0 & & & \\
\hline 51 & 0.760 & & & & 0.036 & & & & 0.061 & & & & 0.127 & & & & 0.015 & & & \\
\hline 52 & 0.728 & 0.811 & & & 0.048 & 0.049 & & & 0.058 & 0.031 & & & 0.153 & 0.107 & & & 0.013 & 0.003 & & \\
\hline 53 & 0.744 & 0.749 & & & 0.023 & 0.044 & & & 0.077 & 0.085 & & & 0.130 & 0.106 & & & 0.026 & 0.017 & & \\
\hline 54 & 0.700 & 0.695 & 0.751 & & 0.046 & 0.059 & 0.059 & & 0.093 & 0.099 & 0.057 & & 0.141 & 0.129 & 0.133 & & 0.020 & 0.018 & 0 & \\
\hline 55 & 0.693 & 0.691 & 0.662 & & 0.043 & 0.073 & 0.045 & & 0.088 & 0.091 & 0.121 & & 0.151 & 0.115 & 0.160 & & 0.025 & 0.031 & 0.012 & \\
\hline 56 & 0.641 & 0.656 & 0.566 & 0.676 & 0.043 & 0.086 & 0.068 & 0.054 & 0.123 & 0.132 & 0.118 & 0.072 & 0.175 & 0.110 & 0.223 & 0.187 & 0.018 & 0.016 & 0.025 & 0.010 \\
\hline 57 & 0.648 & 0.671 & 0.643 & 0.588 & 0.039 & 0.091 & 0.079 & 0.055 & 0.111 & 0.121 & 0.108 & 0.116 & 0.187 & 0.087 & 0.145 & 0.223 & 0.016 & 0.030 & 0.024 & 0.017 \\
\hline 58 & 0.591 & 0.582 & 0.540 & 0.545 & 0.068 & 0.107 & 0.090 & 0.064 & 0.131 & 0.168 & 0.166 & 0.145 & 0.181 & 0.120 & 0.174 & 0.216 & 0.029 & 0.023 & 0.029 & 0.031 \\
\hline 59 & 0.568 & 0.580 & 0.577 & 0.547 & 0.085 & 0.074 & 0.066 & 0.080 & 0.161 & 0.201 & 0.158 & 0.154 & 0.175 & 0.114 & 0.174 & 0.197 & 0.012 & 0.031 & 0.026 & 0.022 \\
\hline 60 & 0.489 & 0.491 & 0.475 & 0.473 & 0.069 & 0.121 & $\overline{0.100}$ & 0.075 & 0.228 & 0.241 & 0.212 & 0.184 & 0.191 & 0.120 & 0.190 & 0.236 & 0.022 & 0.027 & 0.023 & 0.032 \\
\hline 61 & 0.501 & 0.479 & 0.467 & 0.446 & 0.077 & 0.114 & 0.084 & 0.091 & 0.245 & 0.269 & 0.251 & 0.199 & 0.156 & 0.100 & 0.181 & 0.230 & 0.021 & 0.037 & 0.017 & 0.035 \\
\hline 62 & & 0.355 & 0.305 & 0.327 & & 0.127 & 0.135 & 0.112 & & 0.395 & 0.364 & 0.265 & & 0.091 & 0.171 & 0.254 & & 0.032 & 0.025 & 0.042 \\
\hline 63 & & 0.333 & 0.261 & 0.244 & & 0.114 & 0.135 & 0.139 & & 0.409 & 0.402 & 0.326 & & 0.099 & 0.187 & 0.274 & & 0.046 & 0.015 & 0.017 \\
\hline 64 & & & 0.210 & 0.214 & & & 0.167 & 0.121 & & & 0.411 & 0.358 & & & 0.196 & 0.272 & & & 0.016 & 0.035 \\
\hline 65 & & & 0.143 & 0.172 & & & 0.112 & 0.157 & & & 0.572 & 0.421 & & & 0.127 & 0.224 & & & 0.046 & 0.027 \\
\hline 66 & & & & 0.107 & & & & 0.136 & & & & 0.448 & & & & 0.274 & & & & 0.035 \\
\hline 67 & & & & 0.112 & & & & 0.062 & & & & 0.410 & & & & 0.393 & & & & 0.023 \\
\hline
\end{tabular}

See Appendix 1 for sample exclusions. 
Table 10: Retirement Status of Men In The Retirement History Study and Health and Retirement Study

\begin{tabular}{|c|c|c|c|c|c|c|}
\hline \multirow{3}{*}{ Age } & \multicolumn{6}{|c|}{ Self Reported Retirement Status } \\
\hline & \multicolumn{2}{|c|}{ Not Retired } & \multicolumn{2}{|c|}{ Partially Retired } & \multicolumn{2}{|c|}{ Completely Retired } \\
\hline & $\overline{\text { RHS }}$ & HRS & $\overline{\mathrm{RHS}}$ & HRS & $\overline{\mathrm{RHS}}$ & $\overline{\mathrm{HRS}}$ \\
\hline 58 & 0.85 & 0.69 & 0.05 & 0.10 & 0.09 & 0.21 \\
\hline 59 & 0.81 & 0.66 & 0.06 & 0.12 & 0.12 & 0.22 \\
\hline 60 & 0.78 & 0.61 & 0.06 & 0.12 & 0.13 & 0.27 \\
\hline 61 & 0.71 & 0.57 & 0.08 & 0.13 & 0.19 & 0.30 \\
\hline 62 & 0.60 & 0.37 & 0.10 & 0.19 & 0.28 & 0.43 \\
\hline 63 & 0.51 & 0.35 & 0.12 & 0.20 & 0.34 & 0.45 \\
\hline 64 & 0.40 & 0.29 & 0.13 & 0.18 & 0.46 & 0.52 \\
\hline 65 & 0.19 & 0.18 & 0.17 & 0.22 & 0.62 & 0.59 \\
\hline 66 & 0.12 & 0.18 & 0.17 & 0.22 & 0.70 & 0.59 \\
\hline 67 & 0.11 & 0.13 & 0.17 & 0.33 & 0.72 & 0.55 \\
\hline
\end{tabular}

*Outcomes from The Retirement History Study (RHS) are from Gustman and Steinmeier (1984, Table 1). HRS outcomes are from Table 8. The RHS allowed the respondent only three choices when reporting retirement status: not retired, partially retired and completely retired. The HRS allows four choices. Therefore, those included as completely retired in the HRS are those who answered either they are completely retired, or that the question is not relevant. Those not available have been excluded from the base so that the percentages of those reporting they are not retired, partially retired and fully retired sum to 1.0. 
Table 11: Change In Retirement Status For Men In The Retirement History Study and Health and Retirement Study

\begin{tabular}{|c|c|c|c|c|c|c|}
\hline \multirow[t]{3}{*}{ Age } & \multicolumn{6}{|c|}{ Self Reported Retirement Status } \\
\hline & \multicolumn{2}{|c|}{ Not Retired } & \multicolumn{2}{|c|}{ Partially Retired } & \multicolumn{2}{|c|}{ Completely Retired } \\
\hline & RHS & HRS & RHS & HRS & RHS & HRS \\
\hline 58 to 59 & -0.04 & -0.03 & 0.01 & 0.02 & 0.03 & 0.01 \\
\hline 59 to 60 & -0.03 & -0.05 & 0.00 & 0.00 & 0.01 & 0.05 \\
\hline 60 to 61 & -0.07 & -0.04 & 0.02 & 0.01 & 0.06 & 0.03 \\
\hline 61 to 62 & -0.11 & -0.20 & 0.02 & 0.06 & 0.09 & 0.13 \\
\hline 62 to 63 & -0.09 & -0.02 & 0.02 & 0.01 & 0.06 & 0.02 \\
\hline 63 to 64 & -0.11 & -0.06 & 0.01 & -0.02 & 0.12 & 0.07 \\
\hline 64 to 65 & -0.21 & -0.11 & 0.05 & 0.04 & 0.16 & 0.07 \\
\hline 66 to 66 & -0.07 & 0.00 & 0.00 & 0.00 & 0.08 & 0.00 \\
\hline 66 to 67 & -0.01 & -0.05 & 0.00 & 0.11 & 0.02 & -0.04 \\
\hline
\end{tabular}

*First differences calculated from Table 10. 
Table 12: Comparisons Between HRS Wave 1, 51 to 56 Year Olds in 1992, and Warbabies

\begin{tabular}{|c|c|c|}
\hline & HRS 1; 51 to 56 Year Olds Born 1936 to 1941 & $\begin{array}{l}\text { Warbabies; } 51 \text { to } 56 \text { Year Olds Born } 1942 \text { to } \\
1947\end{array}$ \\
\hline Percent of Men Working 1200 Hours or More & 76.5 & 78.0 \\
\hline Percent of Women Working 1200 Hours or More & 53.5 & 60.8 \\
\hline Percent of Employed Men with Pension & 71.3 & 71.9 \\
\hline Percent of Employed Women with Pension & 63.2 & 62.4 \\
\hline $\begin{array}{l}\text { Percent of Pension Covered Men with DB Plan } \\
\text { and/or Both }\end{array}$ & 72.0 & 65.6 \\
\hline $\begin{array}{l}\text { Percent of Pension Covered Women with DB } \\
\text { Plan and/or Both }\end{array}$ & 66.7 & 58.0 \\
\hline $\begin{array}{l}\text { Percent of Pension Covered Men with DB Plan } \\
\text { Only }\end{array}$ & 41.6 & 28.8 \\
\hline $\begin{array}{l}\text { Percent of Pension Covered Women with DB } \\
\text { Plan Only }\end{array}$ & 45.4 & 30.5 \\
\hline Social Security Retirement Age & $\begin{array}{l}\text { Age } 65 \text { for those born } 1936 \text { and } 1937 \text {, } \\
\text { incremented by } 2 \text { months for each year of birth to } \\
65+8 \text { months for those born in } 1941 \text {. }\end{array}$ & $\begin{array}{l}\text { Age } 65+10 \text { months for those born in 1942, and } \\
\text { Age } 66 \text { for those born } 1943 \text { to } 1947 \text {. }\end{array}$ \\
\hline
\end{tabular}




\section{References}

Anderson, Patricia M., Alan L. Gustman and Thomas L. Steinmeier. 1999. "Trends in Male Labor Force Participation and Retirement: Some Evidence on the Role of Pension and Social Security in the 1970s and 1980s". Journal of Labor Economics 17(4), Part 1: 757-783.

Friedberg, Leora. 1999. “The Trend Toward Part-Time Work Among Older Workers”. Paper presented at NBER Summer Institute.

Gustman, Alan L., Olivia S. Mitchell and Thomas L. Steinmeier. "Retirement M easures in the Health and Retirement Survey". J ournal of Human Resources, Vol 30, Supplement (1995), pp. S57-S83.

Gustman, Alan L. and Thomas L. Steinmeier. 1984. "Modeling the Retirement Process for Evaluation and Research". Monthly Labor Review (107)7: 26-33.

Ruhm, Christopher J. 1990. "Bridge Jobs and Partial Retirement". Journal of Labor Economics 8(4): 482-501. 
Appendix 1: Sample Exclusions by Table

\begin{tabular}{|l|l|l|l|}
\hline & Tables 2 and 3 & Tables 4-11 & Appendix 2 \\
\hline Age ineligibles and overlaps & Not included in any wave. & Not included in any wave. & Not included in any wave. \\
\hline Attritors & $\begin{array}{l}\text { Not in any wave where the } \\
\text { interview is not available. Included } \\
\text { in other waves. }\end{array}$ & $\begin{array}{l}\text { Included in sample. Classified } \\
\text { as not available in any wave } \\
\text { where a survey response is } \\
\text { missing. }\end{array}$ & Excluded from all waves. \\
\hline Proxies & $\begin{array}{l}\text { Excluded from any wave where the } \\
\text { interview is obtained from a proxy } \\
\text { respondent. Included in other } \\
\text { waves. }\end{array}$ & $\begin{array}{l}\text { Included in sample. Classified } \\
\text { as not available in any wave } \\
\text { where a survey response is } \\
\text { missing. }\end{array}$ & Excluded from all waves. \\
\hline
\end{tabular}


Appendix 2: Retirement Outcomes By Wave Under Alternative Definitions of Retirement, Excluding Attritors and Proxies From All Waves

\begin{tabular}{|c|c|c|c|c|c|c|c|c|c|c|c|c|c|c|c|c|}
\hline \multirow{3}{*}{ Retirement Measure } & \multicolumn{12}{|c|}{ Retirement Status } & \multirow{2}{*}{\multicolumn{4}{|c|}{ Sample Size With Complete Data }} \\
\hline & \multicolumn{4}{|c|}{ Not Retired (F) } & \multicolumn{4}{|c|}{ Partially Retired $(\mathrm{P})$} & \multicolumn{4}{|c|}{ Completely Retired (R) } & & & & \\
\hline & $\begin{array}{l}\text { Wav } \\
\text { e } 1\end{array}$ & $\begin{array}{l}\text { Wav } \\
\text { e } 2\end{array}$ & $\begin{array}{l}\text { Wav } \\
\text { e } 3\end{array}$ & $\begin{array}{l}\text { Wav } \\
\text { e } 4\end{array}$ & $\begin{array}{c}\text { Wav } \\
\text { e } 1\end{array}$ & $\begin{array}{c}\text { Wav } \\
\text { e } 2\end{array}$ & $\begin{array}{r}\text { Wav } \\
\text { e } 3\end{array}$ & $\begin{array}{c}\text { Wav } \\
\text { e } 4\end{array}$ & $\begin{array}{l}\text { Wav } \\
\text { e } 1\end{array}$ & $\begin{array}{l}\text { Wav } \\
\text { e } 2\end{array}$ & $\begin{array}{l}\text { Wav } \\
\text { e } 3\end{array}$ & $\begin{array}{c}\text { Wave } \\
4\end{array}$ & $\begin{array}{c}\text { Wav } \\
\text { e } 1\end{array}$ & $\begin{array}{c}\text { Wave } \\
2\end{array}$ & $\begin{array}{c}\text { Wav } \\
\text { e } 3\end{array}$ & $\begin{array}{c}\text { Wave } \\
4\end{array}$ \\
\hline Self Reported & 72.2 & 64.3 & 51.6 & 41.9 & 6.6 & 10.3 & 12.3 & 12.9 & 11.4 & 18.4 & 24.7 & 2773.0 & 6671 & 6659 & 6653 & 6653 \\
\hline By Usual Hours/Weeks & 63.0 & 56.5 & 47.7 & 40.8 & 7.6 & 8.1 & 9.7 & 10.2 & 29.4 & 35.4 & 42.5 & 49.0 & 6671 & 6630 & 6625 & 6614 \\
\hline By Usual Hours/Year & 61.2 & 55.7 & 46.8 & 39.7 & 8.6 & 8.7 & 10.3 & 10.9 & 30.1 & 35.6 & 42.8 & 49.4 & 6671 & 6595 & 6586 & 6572 \\
\hline By Leaving 10+ Year Job & 60.0 & 49.7 & 38.1 & 28.6 & 22.7 & 24.2 & 25.8 & 26.0 & 17.2 & 26.1 & 36.0 & 45.4 & 3754 & 3645 & 3556 & 3489 \\
\hline By Leaving 20+ Year Job & 64.0 & 51.5 & 38.5 & 27.9 & 19.1 & 20.8 & 23.4 & 23.8 & 16.9 & 27.6 & 38.1 & 48.4 & 1951 & 1877 & 1813 & 1777 \\
\hline By Hourly Wage & 59.0 & 49.9 & 42.1 & 35.0 & 10.1 & 11.8 & 12.4 & 12.6 & 30.9 & 38.3 & 45.5 & 52.3 & 6595 & 6128 & 6187 & 6189 \\
\hline By Weekly Earnings & 57.4 & 47.4 & 39.0 & 32.1 & 11.7 & 14.2 & 15.5 & 15.6 & 30.9 & 38.3 & 45.5 & 52.3 & 6595 & 6128 & 6187 & 6189 \\
\hline By Social Security Receipt & 95.4 & 87.3 & 74.1 & 60.5 & n.a. & .n.a. & n.a. & n.a. & 4.6 & 12.7 & 25.9 & 39.5 & 5986 & 5966 & 5981 & 5981 \\
\hline
\end{tabular}

Source: Authors' calculations. Definitions of retirement outcomes are presented in Table 1. All results are weighted using the weights from wave1. Percentages not retired, partially retired and fully retired do not sum to 1.0 due to inclusion of those answering not relevant in the population base.

See Appendix 1 for sample exclusions. Sample sizes differ between the waves only because of don't knows, refusals, or incomplete data. 